\title{
UNUTULMA HAKKININ BİR “INSAN HAKKI”NA DÖNÜŞME YOLCULUĞU
}

\section{Yaşar SALİHPAŞAOĞLU* Burcu DEĞİRMENCIOĞLU ${ }^{* *}$}

“... geçmiş yaşam doludur, kızdırır, baş kaldırtır, yaralar, o kadar ki, bu yüzden onu yok etmek ya da yeniden yaratmak isteriz. Geleceğe egemen olunmak istenilmesinin nedeni, geçmişi değiştirecek güce sahip olmaktan başka bir şey değildir."

\section{$\ddot{O} Z$}

Bilişim ve iletişim teknolojisinde yaşanan gelişmelerin kişisel verilerin biriktirilmesini, onlara ulaşılmasını ve onların analiz edilmesini kolaylaştırması, unutulma hakkı adı verilen yeni bir hakkı gündeme getirmiştir. Terimin yarattı̆̆ ilk izlenime rağmen, bu hakkın bir insan hakkı olarak görülmediği açıktır. Ancak insan doğası ve bireyin kendisiyle ilgili bilgilerin geleceğini belirleme otonomisi ile doğrudan ilişkili olan bu hakkın bir insan hakkı olarak kabul edilmesi günümüz dünyası açısından elzemdir. Söz konusu hakkın, Google v. Spain kararının ardından çeşitli uluslararası belgelerde düzenlenmesi, Google'ın unutulma hakkına yönelik talepleri dikkate almaya başlaması ve muhalefet şerhlerinde de olsa Avrupa Insan Hakları Mahkemesi kararlarında hakk ifade eden terime yer verilmesi bu anlamda önemli bir gelişmedir. Bununla birlikte unutulma hakkının insan hakkı olarak kabul edilmesinin önünde teorik ve pratik pek çok engel bulunmaktadır.

Anahtar Kelimeler: Unutulma Hakkl, Silme Hakkı, Özel Hayata Saygl Hakkı, Bilgilendirme Otonomisi, Avrupa Birliği Adalet Divanı.

* Doç. Dr., Ankara Hacı Bayram Veli Üniversitesi, Hukuk Fakültesi, Genel Kamu Hukuku Anabilim Dalı, E-mail Adresi: yasar.salihpasaoglu@hbv.edu.tr, ORCID ID: 0000-0002-3370-9951.

** Arş. Gör., Ankara Sosyal Bilimler Üniversitesi, Hukuk Fakültesi, Genel Kamu Hukuku Anabilim Dal, E-mail Adresi: burcu.degirmencioglu@asbu.edu.tr, ORCID ID: 0000-0001-5721-9933.

1 KUNDERA, s.32.

DOI : 10.34246/ahbvuhfd. 733270

Yayın Kuruluna Ulaştığı Tarih : 27/03/2020

Yayınlanmasının Uygun Görüldüğü Tarih: 07/04/2020 


\title{
THE JOURNEY OF TRANSFORMATION OF THE RIGHT TO BE FORGOTTEN TO A "HUMAN RIGHT"
}

\begin{abstract}
The fact that developments in information and communication technology facilitates the accumulation, access and analysis of personal data has brought a new right called right to be forgotten. Despite the first impression of the term, it is clear that this right is not seen as a human right. However, it's essential for today's world that this right, which is directly related to the informational self-determination about human nature and the individual himself, as a human right. It is an important development in this sense that the right in question was regulated in various international documents following the decision of Google v. Spain, that Google started to consider the demands for the right to be forgotten and that the term expressing the right in the decisions of the European Court of Human Rights, even in dissenting opinions. However, there are many theoretical and practical obstacles to accepting the right to be forgotten as a human right.
\end{abstract}

Keywords: Right to be Forgotten, Right to Delete, Right to Respect for Private Life, Informational Self- Determinations, Court of Justice of European Union.

\section{GIRIŞ}

Toplumsal hayatın ve hukukun değişimine neden olan en önemli faktörlerden biri bilim ve teknolojide yaşanan gelişmelerdir. Uygarlık tarihi bir yönüyle bilim ve teknoloji tarihidir. İlkel yaşam biçimlerinden bugüne bilim ve teknoloji alanında görülen gelişmeler insan davranışlarını etkileyen, toplumsal yaşamın yönünü belirleyen, yeni kurum ve kuralların ortaya çıkmasına yol açan dönüm noktalarını oluşturur. ${ }^{2} \mathrm{Bu}$ dönüm noktalarından biri de yeni bir çağa girilmekte olduğu izlenimi veren bilişim ve iletişim teknolojilerinde yaşanan gelişmelerdir. Bilgi bolluğu ile damgalanan bu çağ bilgi çağı, oluşan yeni toplum bilgi toplumu olarak adlandırılmaktadır. ${ }^{3}$

Bilgi toplumunun ayırt edici yönlerinden biri ve belki de en önemlisi, 20. yüzyılın son çeyreğinden itibaren kendini göstermeye başlayan ve bugün sunduğu olanaklar ile hayatımızın çok büyük bir kısmını kuşatan bilişim teknolojisindeki gelişmelerdir. Günümüzde bilgisayar ve akıllı telefonlarda

\footnotetext{
2 SALİHPAŞAOĞLU, s.56.

3 SCHILLER, S.274.
}

362 Ankara Hacı Bayram Veli Üniversitesi Hukuk Fakültesi Dergisi C. XXIV, Y. 2020, Sa. 2 
kullanılan sayısız uygulama ve arama motorları hayatı kolaylaştırmanın yanında kişilerin fotoğraf, video, e-posta adresi, telefon numarası, iletişim kurduğu kişiler, boş zaman geçirme tercihleri, tüketim alışkanlıkları, sevdikleri, nefret ettikleri, yaptığı araştırmalar, gerçekleştirdiği görüşmeler gibi daha birçok konu hakkında sayısız veriyi de biriktirmektedir. Yine bu sahada yaşanan gelişmeler bu verilere ulaşılmasını, bunların analiz edilmesini ve paylaşılmasını da kolaylaştırmaktadır. ${ }^{4} \mathrm{Bu}$ durum hayatı yaşanır kılan, acıların etkisini azaltan, insanın değişmesine ve dönüşmesine zemin hazırlayan unutma ve unutulmayı neredeyse olanaksız kılmaktadır. İnsanın doğasına aykırı olan ve onu geçmişine indirgeyen bu gelişmeler unutulma hakkı (right to be forgotten) adı verilen yeni bir hakkı gündeme getirmiştir.

Son zamanlarda dünyada ve Türkiye'de bir kısmı kişisel verilerin korunması bağlamında, bir kısmı ise bağımsız bir konu olarak unutulma hakkına dair pek çok makale, tez ve kitap yazılmıştır. Özellikle Türkiye'de bu konuya ilişkin yapılan çalışmaların neredeyse tamamında, unutulma hakk1 herhangi bir temellendirme yapılmadan, çeşitli uluslararası hukuk düzenlemelerinden ve Avrupa Birliği Adalet Divanı (ABAD) ${ }^{5}$ ile Avrupa İnsan Hakları Mahkemesinin (AİHM $)^{6}$ kararlarından hareketle bir insan hakkı olarak ele alınmıştır. ${ }^{7}$ Oysa unutulma hakkının gerek uluslararası hukuk metinlerinde gerekse uluslararası yargı kararlarında bir insan hakkı olarak kabul edildiğini söylemek bugün için çok zordur. Bununla birlikte bir hak olarak ortaya çıktığ 1 günden bugüne unutulma hakkının bir insan hakkına dönüşme yolculuğu içerisinde olduğu da görülmektedir. Henüz tamamlanmamış bu yolculuk hem hakkı ifade etmek için kullanılan terminolojide, hem uluslararası düzenlemelerde hem de yargı kararlarında kendini göstermektedir.

$\mathrm{Bu}$ çalışmada unutulma hakkının neden bir insan hakkı olarak kabul edilmesi gerektiği ve başlangıçtan bugüne uluslararası hukuk metinlerinde ve yarg1 kararlarında nasıl bir gelişim gösterip, ele alındığ 1 , başka bir ifadeyle insan hakları yolculuğunda ne kadar mesafe katettiğini ortaya konulmaya çalışılacaktır. $\mathrm{Bu}$ nedenle hakkın kapsamı, sınırları, diğer haklarla ilişkisi, ulusal hukuklardaki düzenlemeler ve ulusal yargı organlarının söz konusu hakka yaklaşımı çalışmanın kapsamı dışında bırakılacaktır.

4 HAMMARBERG, s.48; YAVUZ, s. 19.

5 Court of Justice of the European Union (CJEU).

6 European Court of Human Rights (ECHR).

7 Bkz. ÖZ DEMETOĞLU, s.59, 66; AKYÜZ BİLGE, s.214, 241; YILDIZ, s.199; YAVUZ, s.43, 47; SÖZÜER, s.1, 79, 185, 189, 190, 191; GÜLENER, s.226, 245; AKGÜL, s.19 vd. 


\section{TERMINOLOJI SORUNU}

Unutulma hakkı fikrinin kökleri, 1966 yılından beri Fransız hukukunda bilinen droit à l'oubli ve 1985 yılında İtalya'da mahkeme kararlarında karşımıza çıkan diritto all'oblio kavramlarına dayanmaktadır. Daha çok kişisel verilerin korunması kapsamında görülen suç geçmişinin ve devletin elindeki kayıtların belirli bir süre sonra silinmesi hakkını güvence altına alan söz konusu ${ }^{8}$ ifadeler İngilizceye right to oblivion ya da right to be forgotten olarak çevrilmiştir. Cécile de Terwangne tarafından aynı anlama geldiği iddia edilen ${ }^{9}$ söz konusu ifadelerin Türkçe karşıllğ̆ unutulma hakkıdır.

20. yüzyllın son çeyreğinde, bilgi ve iletişim teknolojisinde yaşanan gelişmeler, Fransız ve İtalyan hukukunda yer alan söz konusu hakkın kapsamının yeniden belirlenmesini ve kişilere ait bilgilerin internet ortamında serbestçe dolaşımı ile bireyin bu konuda belirleyici olması arasında yeni bir denge kurulmasını gerektirmiştir. ${ }^{10}$ İşte bu denge, hukuki düzenlemelerde ve doktrinde silme hakk (right to delete) ${ }^{11}$, toplumsal unutkanllk (social forgetfullness) ${ }^{12}$, kalıcl olarak silme hakkl (right to erasure) ${ }^{13}$ ve unutulma hakkı (right to be forgotten/ right to oblivion) gibi çeşitli terimlerle ifade edilen ve kapsamı kaynağından farklılaşan yeni bir hak ile kurulmuştur.

Çoğu zaman birbirinin yerine kullanılan söz konusu terimlerden hangisinin hakkı ifade etmek için daha uygun olduğu doktrinde tartışma konusu olmuştur. Paul Bernal, söz konusu hakkı ifade etmek için kullanılan terimlerin lafzından hareketle, başkalarına sorumluluk yükleyen unutulma hakkl yerine veri sahibinin doğrudan harekete geçmesine vurgu yapan silme hakkının kullanılması gerektiğini savunmuştur. Ona göre, hakkın hayata geçirilmesi konusunda başkalarına sorumluluk yükleyen unutulma hakkı, neyi konuşup konuşmayacağımıza müdahale ederek ifade hürriyetine sınırlama

\footnotetext{
BROCK, s. 24; COFONE, s.2.

9 TERWANGNE, s.82.

10 TERWANGNE, s.82.

11 Bkz. CONLEY; BERNAL.

12 BLANCHETTE/JOHNSON, s.33-45.

13 Kişisel verilere ilişkin uluslararası hukuk metinlerinde sıklıkla karşımıza çıkan ve GDPR'ın 17. maddesinin başlığına adını veren right to erasure, Türkçeye silme hakkı olarak çevrilmiştir. Böyle bir çeviri doğal olarak söz konmuşu terimin right to delete ile karıştırılmasına yol açmaktadır. Bu nedenle, internet ortamından kalıcı olarak silinme anlamına gelen erasure sözcüğünü biz kalıcı olarak silme olarak Türkçeye çevirdik. Bkz. SHARMA, s.212.
} 
getirmekte ve sansür çağrışımı yapmaktadır. ${ }^{14}$ Ancak hak sahibi olmak; sadece bir şey yapmaya yetkili olmak değil, aynı zamanda bir şeyi talep edebilmek anlamına gelir. Bu açıdan bakıldığında hak, sahibine, bir şeyi yapabilme ya da bir şeyi talep edebilme yetkisi sağlarken, diğer kişilere de bu yetkinin tanınması, kullanılmasına engel olmama ve sayg1 gösterme ödevi yükler. ${ }^{15}$ $\mathrm{Bu}$ nedenle unutulma hakkının, mutlak bir hak niteliğinde olmayan ifade hürriyetini sınırlamasında herhangi bir sakınca yoktur. Ayrıca ifade hürriyetini sınırlamayan bir unutulma hakkının hayata geçirilmesi zaten mümkün değildir.

Blanchette ve Johnson, herkesin hayata yeni bir başlangıç yapabilmesi için unutkanlığa ihtiyaç duyulduğunu söyler. Onlara göre, unutkanlığın olmadığ 1 ve her şeyin kayıt altına alındığı bir dünya demokrasinin gelişmesine elverişli değildir. Unutkanlığın birey ve toplum için faydalı olduğunu belirten yazarların bu düşünceyi ifade etmek için kullandığı terim toplumsal unutkanlıktır. Bununla birlikte hukuktan ziyade sosyal-psikolojide kullanılan söz konusu terim hem unutulma hakkını karşılamaktan uzaktır, hem de terimi kullanan yazarlarca unutulma hakkını ifade eden bir alternatif olarak sunulmamıştır. ${ }^{16}$

Terwangne ise unutulma hakkı ile kalıcı olarak silme hakkının aynı şeyi ifade etmediğini, kalıcı olarak silme hakkının kişiye kendisine ait verileri ortadan kaldırma olanağı tanırken, unutulma hakkının geçmişteki verinin gün yüzüne çıkartılmasını ve bugüne taşınmasını engellediğini iddia etmektedir. ${ }^{17}$

Bize göre de hakkı ifade eden en uygun terim unutulma hakkıdır. Söz konusu hakkın insan hakkına dönüşebilmesi için silme, kalıcı silme gibi bir eyleme değil, unutulma gibi bir sonuca vurgu yapan bir terime ihtiyaç vardır. Elde edilmek istenen amaca ya da sonuca ulaşmaya hizmet eden araçların hakkın bizatihi kendisi olarak görülmesi, sadece hakkın koruduğu değerin gölgede kalmasına değil, aynı zamanda hakkın kapsamının daralmasına da neden olmaktadır. Nasıl ki internete girme hakk1, ifade hürriyetinin bir uzantıs1 olarak kabul edilen bilgiye erişim hakkı ile aynı şey değilse, silme hakkı da unutulma hakkı ile aynı şey değildir. Silme olsa olsa unutulma hakkının hayata geçirilmesine hizmet eden anonim hale getirme, düzeltme, engellenme, yok etme gibi birçok araçtan sadece bir tanesidir.

\footnotetext{
14 BERNAL.

15 UYGUN, s.478; KALABALIK, s.26-27.

16 BLANCHETTE / JOHNSON, s.33-45.

17 TERWANGNE, s.83.
}

Ankara Hacı Bayram Veli Üniversitesi Hukuk Fakültesi Dergisi C. XXIV, Y. 2020, Sa. 2365 
Unutulma hakk1 terimine ilk yer veren uluslararası belge, Avrupa Konseyinde, üye ülkelerin hukuk alanında işbirliğini yürütmek üzere oluşturulan Hukuk Alanında Iş̧birliği Komitesi ${ }^{18}$ bünyesinde faaliyetlerini sürdüren Veri Koruma Uzmanlar Komitesinin ${ }^{19}$ yeni teknolojiler karşısında kişisel verilerin korunmasına ilişkin 1989 tarihli çalışmasıdır. Söz konusu çalışmada bu alanda oluşturulacak bir düzenlemede dikkate alınması gereken unsurlar sayılırken açık bir şekilde unutulma hakkı terimi, saklanan verilerin belirli bir süre sonunda silinmesi anlamında da olsa kullanılmıştır ${ }^{20}$.

Unutulma hakkının, unutulma hakkı terimini kullanarak, bir hak olarak, açıkça düzenlendiği ilk uluslararası hukuki metin ise Avrupa Parlamentosu tarafindan 27 Nisan 2016 tarihinde yayımlanarak 25 Mayıs 2018 tarihinde yürürlüğe giren ve tüm birlik üyeleri için bağlayıcı olan Avrupa Birliği Genel Veri Koruma Tüzügüüür (GDPR). ${ }^{21}$ 95/46/EC sayıl Direktifi ${ }^{22}$ yürürlükten kaldıran bu Tüzüğ̈̈n Beyanlar (Recitals) bölümünün 65 ve 66. maddelerinde de bu terime açıkça yer verilmiştir. ${ }^{23}$ Aynı Tüzüğün 17.maddesinin başlığı ise "silme hakk1 (right to erasure) / unutulma hakk1 (right to be forgotten)"dir. Her ne kadar madde başlı̆̆ında silme hakkı ile birlikte kullanılsa ve madde metninde unutulmadan hiç bahsedilmese de bu durum unutulma hakkının silme talebinin ötesinde bir insan hakkına dönüşme yolculuğunda önemli bir gelişme olmuştur.

18 Council of Europe, European Committee on Legal Co-operation (CDCJ), (https://www. coe.int/en/web/cdcj/home? , erişim:16.01.2020).

19 Committee of Experts on Data Protection (CJ-PD).

20 European Council, Committee of Experts on Data Protection (CJ-PD), "New Technologies: a challenge to privacy protection ?", 1989, (https://rm.coe.int/CoERMPublicCommonSearchServices/DisplayDCTMContent?documentId=0900001680684607, erişim:15.12.2019).

${ }^{21}$ General Data Protection Regulation (GDPR), (https://eur-lex.europa.eu/legal-content/EN/ TXT/HTML/?uri=CELEX:32016R0679\&from=EN\#d1e40-1-1 , erişim:16.12.2019).

2224 Ekim 1995 tarihli ve 95/46/EC sayılı "Kişisel Verilerin İşlenmesi ve Bu Türdeki Verilerin Serbest Dolaşımı Bağlamında Bireylerin Korunmasına İlişkin Avrupa Parlamentosu ve Konseyi Direktifi" ise AB bünyesinde yapılan kişisel verilerin korunmasına ilişkin önemli metinlerden biri olmuştur. The European Parliament and the Council of The European Union, Directive 95/46/EC of The European Parliament and of the Council of 24 October 1995, (https://eur-lex.europa.eu/legal-content/EN/TXT/PDF/?uri=CELEX:31995L0046\&from= $\mathrm{EN}$, erişim:27.03.2020).

23 General Data Protection Regulation Recitals, Recital 65 "Right to Rectification and Erasure", (https://gdpr-info.eu/recitals/no-65/, erişim:15.01.2020); General Data Protection Regulation Recitals, Recital 66 "Right to be Forgotten", (https:/gdpr-info.eu/recitals/no-66/, erişim:15.01.2020). 
Bununla birlikte hakkın unutulma hakkı terimiyle kullanılmasının yaygınlaşması Avrupa Komisyonunun Adalet, Temel Haklar ve Yurttaşlıktan sorumlu Başkan Yardımcısı Viviane Reding'in, Brüksel'de gerçekleştirilen bir konferansta yaptığ 1 konuşma ve ABAD'ın Google v. Spain kararı ile olmuştur.

\section{UNUTULMA HAKKININ ÖNEMI VE TEMELLENDIRILMESI}

A. "Tanr1 Affeder, İnternet Asla"

30 Kasım 2012'de Viviane Reding, Brüksel'de gerçekleştirilen AB Veri Koruma ve Mahremiyet Konferansinda (The European Data Protection and Privacy Conference) yaptığı konuşmada unutulma hakkının önemini vurgulamak için şu ifadeyi kullanmıştır: "Tanrı affeder; ama internet asla! İşte 'unutulma hakkı'nın benim için neden önemli olduğu bu cümlede gizlidir" 24

Reading'in de söylediği gibi, Tanrı affeder; ama internet affetmez ve unutmaz. Unutmak, unutulmak, affedilmek inanç sistemlerinin temelini oluşturur. İnananlara göre affedici olan Tanrı, tövbekarların geçmişlerine sünger çekmelerine, yeni bir başlangıç yapabilmelerine olanak tanır. Başka bir ifadeyle insanların geçmişlerinden kurtulmalarına, kendilerini yeniden inşa etmelerine, pişmanlıklarından ders çıkararak hayatlarına yeni bir yön vermelerine izin verir. Oysa günümüzde dijital teknoloji ve küresel ağlar nedeniyle, unutmak ve unutulmak istisna haline gelmiş ${ }^{25}$, geçmiş dijital derilerimize kazınmış bir dövmeye dönüşmüştür ${ }^{26}$. Özellikle gençlikte yaşanan tecrübeler, hayatın ilerleyen yıllarında hata olarak algılanıp unutmak ve unutturulmak istenebilir. Yeni iletişim teknolojilerini ve sosyal medyay1 kullanan kişilerin \%38'inin 9-12, \%77'sinin ise 13-16 yaş aralığındaki ${ }^{27}$ gençlerden oluşması, ilerleyen zamanlarda unutulma talepleriyle daha fazla karşılaşılacağını göstermektedir. ${ }^{28} \mathrm{Bu}$ taleplere cevap verebilmek tek tek

24 REDING, Viviane. The European Data Protection and Privacy Conference, Brussels, 30 November 2010. (https://ec.europa.eu/commission/presscorner/detail/en/SPEECH_10_700, erişim:04.12.2019). REDING, Viviane. The EU Data Protection Reform 2012: Making Europe the Standard Setter For Modern Data Protection Rules in Digital Age, 22 January 2012, Munich. (http://europa.eu/rapid/press-release_SPEECH-12-26_en.htm, erişim:04.01.2019).

25 SCHÖNBERGER, s.1.

26 LASICA.

27 EU Kids Online, (http://www.lse.ac.uk/media-and-communications/research/research-projects/eu-kids-online, erişim:28.03.2019); Gençler ve sosyal medya konulu başka bir anket çalışmasında yer alan veriler için ayrıca bkz. GÜLENER / TÜRKÖLMEZ.

28 CIAVARELLA/ TERWANGNE, s.158.

Ankara Hacı Bayram Veli Üniversitesi Hukuk Fakültesi Dergisi C. XXIV, Y. 2020, Sa. 2367 
bireyler ve bir bütün olarak toplumun sağlığı ve düzeni için önemlidir ${ }^{29}$.

Unutmak ve unutulmanın esas olduğu bir dönemden giderek dijitalleşen bir dünyada yaşamanın kaçınılmaz hale gelmesiyle birlikte, unutmak ve unutulmanın istisnaya dönüşmesi insan haklarının gerekçesi olarak gösterilen insan doğas1 ve özgürlüğünü de tehdit etmeye başlamıştır. Gerçekten de "hafıza-i beşer nisyan ile maluldür" vecizesinde de vurgulandığı gibi insanın doğasında unutmak vardır; ancak doğasında istifçilik ve ifşa olan internet bunu neredeyse olanaksız hale getirmektedir. Unutmak ve unutulmanın değil, hatırlamak ve hatırlatmanın geçerli olduğu internet ortamında insanın acılarını, hata olarak gördüklerini geride bırakması, hem iç dünyasında hem de başkalarının gözünde kendini değiştirmesini zorlaştırmaktadır. George Orwell'ın 1984 isimli distopyasında "Geçmişi kontrol eden geleceği kontrol eder. Bugünü kontrol eden geçmişi kontrol eder." ${ }^{0}$ şeklinde ifade edildiği üzere, iletişim ve bilişim alanında yaşanan gelişmeler karşısında, unutulma hakkının olmadığı bir ortamda bireyin geçmişini kontrol etmesi ve geleceğini inşa etmesi beklenemez. Böyle bir ortam insanın doğasına içkin olduğu kabul edilen istenç (irade, will) özgürlüğü ve kendini gerçekleştirme kapasitesine ${ }^{31}$ aykırı bir biçimde onu geçmişe hapsetmekte, değişmesini ve dönüşmesini reddetmekte, başkalarının zihninde onu dondurmaktadır. Bu ise, onun kendine dair bilgilendirme konusundaki otonomisini elinden almaktadır. Eder"

B. Bilgilendirme Otonomisi: "Geçmişi Kontrol Eden Geleceği Kontrol

Unutulma hakkının tanınmadığı internet ortamında insanın kendine yeni bir şekil vermesi, kendi dünyasında ve başkalarının zihninde kendini değiştirmesi ve pişmanlığının görünür olabilmesi oldukça zordur. Oysa insanın geçmişini bir kenara bırakarak geçmişiyle değil, şimdiki haliyle bilinmesi, kendisini değiştirebilmesi, pişmanlık duyarak hayatına yeni bir yön vermesi, aynı şekilde elde ettiği ya da ulaştığı yeni bilgilerle birlikte yanlışlarını düzeltebilmesi ve dünkü doğrularının yanlışlığını fark etmesi onun bilgilendirme otonomisi ile yakından ilişkilidir.

Bireysel özerklikle bağlantılı olarak, bireylerin kendilerine ait bilgileri düzeltme, silinmesini isteme, bağlamı dışında bilinmesini istememeyi ifade

29 SCHÖNBERGER, s.6-7.

30 ORWELL, S.59.

31 İnsan haklarının doğalcı temellendirilmesi için bkz. ERDOĞAN, s.56-65. 
eden unutulma hakkı düşüncesi, kişinin geçmişinden ibaret olmadığını ortaya koymaktadır ${ }^{32}$. Geçmiş geçmişte kalmıştır ve kişi isteyene kadar ya da haklı bir sebep olmaksızın tekrar yüzeye çıkartılmamalıdır. ${ }^{33} \mathrm{Bu}$ durum, bireysel özerklik temelinde, insanların kendileriyle ilgili bilgilerin geleceğini belirlemek ${ }^{34}$ olarak tanımlanabilecek bilgilendirme otonomisi (informational self- determination, informationelle selbstbestimmung, informational autonomy) 'nin bir gereğidir.

Bireyin kendisine ait bilgilerin hangilerinin, ne dereceye kadar başkalarıyla paylaşılacağına karar verme özgürlüğü olan bilgilendirme otonomisi kavramı, Alman Anayasa Mahkemesinin 1983 tarihli karar ${ }^{35}$ ile inşa edilmiştir. Nüfus sayımı karart ${ }^{36}$ olarak bilinen bu davada, Mahkeme söz konusu kavramı Federal Almanya Cumhuriyeti Anayasasinin devlete insan onur ve haysiyetini koruma yükümlülüğü yükleyen birinci ve kişiye kendini serbestçe gelişstirme hakkl veren ikinci maddesi temeline oturtmuştur ${ }^{37}$.

Bilgilendirme otonomisi kavramı özünde kişisel bilgilerin ifşası ve kullanımı hakkında bireyin belirleyici olmasıyla ilgilidir ${ }^{38}$. Alman Anayasa Mahkemesinin görüşüne göre, bu hak sadece bireyi değil, aynı zamanda demokratik düzeni korumak için de gereklidir ${ }^{39}$. Kişisel verilerin kim tarafindan, nasıl, ne zaman ve hangi sınırlara bağlı olarak paylaşılacağının birey tarafindan belirlenmesi, toplumsal bir düzen yaratacaktır. Mahkeme ayrıca, temel bir hak olarak tanımladı $\breve{g}^{40}$ bilgilendirme otonomisini mutlak bir hak olarak tasarlamadığına, baskın bir kamu yararı olması halinde

32 TERWANGNE, s.87.

33 TERWANGNE, s.83.

34 KÜZECİ, s.56.

3565 BVerfGE 1, decision of 15.12.1983, (https://www.bundesverfassungsgericht.de/SharedDocs/Entscheidungen/DE/1983/12/rs19831215_1bvr020983.html, erişim:16.01.2019).

36 "Census Case" için bkz. RINGELHEIM, s.25; "Census decision" için bkz. FLAHERTY, s.77; SCHWARTZ, s.686; STABEN, s.1; FIALOVA, s.47; SCHAAR, s.4; KODDE, s.19; HORNUNG/SCHNABEL, s.84-88; SCHWARTZ, s.562.

37 Federal Alman Cumhuriyeti Anayasas1, (http://www.adalet.gov.tr/duyurular/2011/eylul/ anayasalar/ulkeana/pdf/08-ALMANYA\%20209-276.pdf, erişim: 26.12.2019).

38 RINGELHEIM, s.25; Ayrıntılı bilgi için ayrıca bkz. EBERLE, s.965- 1016. Alman Anayasa Mahkemesi bilgilendirme otonomisi kavramını, "bireyin kişisel bilgilerinin ifşasını ve kullanımını kendisinin belirlemesi hakkı" olarak tanımlar. STABEN, s.1-2'den naklen.

39 RINGELHEIM, s.25.

40 "Fundamental right to informational self- determination". SCHAAR, s.4. 
bu hakkın sınırlanabileceğine, istisnai hal dışında, herkesin kendisine ait verilerin kullanımı ve devri konusunda belirleme hakkına sahip olduğuna karar vermiştir. ${ }^{41}$ Bireyin ne zaman ve hangi sınırlar içerisinde yaşam ilişkilerini alenileştireceğine karar verme hakkı kendisine aittir ${ }^{42}$. Bu yönüyle bakıldığında bilgilendirme otonomisi, kişinin geçmişte kalmış, bugün için geçerli olmayan eski bilgilerle değil, değişim ve dönüşümünü yansıtan güncel bilgilerle kendini ifade etmesidir.

Unutulma hakkının, insan hakkı olarak temellendirilmesinde önemli bir dayanak oluşturan bilgilendirme otonomisi kavramı, AİHM kararlarında da yer bulmuştur. Alman Anayasa Mahkemesinin kararından bir y1l sonra, 1984 yılında, Malone v. The United Kingdom davasında söz konusu kavram bilgilendirme otonomisi hakk (right to informational self- determination) olarak karşımıza çıkmıştır. Yargıç Pettiti'nin mutabık görüşünde (concurring opinion) bilgilendirme otonomisi, Alman Anayasa Mahkemesinin kararına gönderme yapılarak "bireyin özel hayatıyla ilgili verileri hangi sınırlar dahilinde belirleyebileceğine karar verme ve kendisini 'kamu mülkü’ yapma eğilimine karşı koruma hakkı"43 olarak tanımlanmıştır. Aynı şekilde 2013 tarihli Youth Initiative for Human Rights v. Serbia ${ }^{44}$ ve 2016 tarihli Magyar Helsinki Bizottság v. Hungary ${ }^{45}$ kararlarında da mutabık görüşte yer verilen bu hak, 2017 ve sonrast kararlarda Mahkemenin değerlendirmesi (The

41 RINGELHEIM, s.25.

42 ŞİMŞEK, s.115. Alman Anayasa Mahkemesi, bilginin "gizlilik” niteliğini incelemeksizin tamamen, bilginin toplumsal niteliğini dikkate alarak, bireylere tanınan bilgilendirme otonomisi hakkının devlete bazı yükümlülükler yüklediğini ifade etmiştir. Veriler konusunda münhasır kontrol veya mülk menfaati vermek yerine, bilgilendirme otonomisi Devlet'i kişisel özerkliğe saygı gösterilmesi için veri işleme organize etmeye zorlar. Bu nedenle, devlet etkilenen kişilerin kendileriyle ilgili verileri kimlerin kullanacağını belirlemesine izin vermek amacıyla bu verilerin işlenmesini yapılandırmak için önemler almalıdır. SCHWARTZ, s.690.

43 AİHM, Malone v. The United Kingdom, B.N.: 8691/79, 02.08.1984, “Concurring Opinion of Judge Pettiti".

44 Söz konusu davada, Yargıç Sajó and Vučınıć'in mutabık karșı görüşünde bilgilendirme otonomisi terimine yer verilmiş ve 10.madde kapsamında bilgiye erişim hakkının bilgilendirme otonomisi ile ilișkili olduğu vurgulanmıștır. AİHM, Youth Initiative for Human Rights v. Serbia, B.N.: 48135/06, 25.06.2013, “Joint Concurring Opinion of Judges Sajó and Vučinić".

45 Söz konusu kararda Yargıç Nussberger ve Keller, Alman Anayasa Mahkemesi'ne atıfta bulunarak bilgilendirme otonomisi hakkını, kişisel verilerin korunması ve kullanımının düzenlenmesiyle ilişkilendirmişlerdir.

AİHM, Magyar Helsinki Bizottsag v. Hungary, (Grand Chamber), B.N.: 18030/11, 08.11.2016, "Concurring Opinion of Judges Nussberger and Keller", §7. 
Court's assessment) bölümünde karşımıza çıkmaya başlamıştır. Sözleşmenin 8. maddesine ilişkin değerlendirme yapılırken başvurulacak ilkelerin ifade edildiği bölümde bilgilendirme otonomisi hakkına açıkça yer verilmiştir. Mahkemeye göre, "Sözleşmenin 8.maddesi bilgilendirme otonomisi hakkını güvence altına almaktadır. Bu hak, bireylerin verilerinin gizliliği hakkına güvenmelerine imkan vermektedir." 46

\section{IV. ÖNEMLİ BİR DÖNÜM NOKTASI: GOOGLE V. SPAIN KARARI VE ETKILERI}

ABAD tarafından verilen 2014 tarihli Google Spain SL and Google Inc. v Agencia Española de Protección de Datos (AEPD) and Mario Costeja González (Google v. Spain) kararı unutulma hakkının insan hakkına dönüşme yolculuğunda bir dönüm noktası niteliğindedir. ${ }^{47}$

Karara konu olan olayda başvurucu Mario Costeja González, kendi ismini Google arama motoruna yazdığında La Vanguardia gazetesinin González'in sosyal güvenlik borçları sebebiyle mülkünü satmasını haber yapan 19 Ocak ve 9 Mart 1998 tarihli sayfasına ait linklerin ${ }^{48}$ kaldırılması veya düzeltilmesi istemiyle İspanyol Veri Koruma Ajansina (Agencia Española de Protección de Datos -AEPD) 5 Mart 2010 tarihinde bir başvuru yapmıştır ${ }^{49}$. İspanyol Veri Koruma Ajansı, Google'ın söz konusu linkleri kaldırması yönünde karar almıştır. Bu karar Google tarafindan Ulusal Yüksek Mahkeme (Audiencia Nacional)'ye taşınmıştır. Yüksek Mahkeme, davaya konu olan olayın kişisel verilerin korunması ve arama motorlarının yükümlülüğü bağlamında, $\mathrm{AB}$ 'nin 95/46/EC sayılı Direktifin dikkate alınarak değerlendirilmesi gerektiğini ifade etmiştir ${ }^{50}$. Mahkeme, karar vermeden önce ABAD'tan ön karar (preliminary

46 AİHM, M.L. and W.W. v. Germany, B.N.: 60798/10, 65599/10, 28.06.2018, §87; AİHM, Benedik v. Slovenia, B.N.: 62357/14, 24.04.2018, §103; AİHM, Satakunnan Markkinapörssi Oy and Satamedia Oy v. Finland, B.N.: 931/13, 27.06.2017, §137.

47 BYGRAVE, s.35.

48 La Vanguardia, Edición del lunes 19 de enero 1998. (http://hemeroteca.lavanguardia.com/

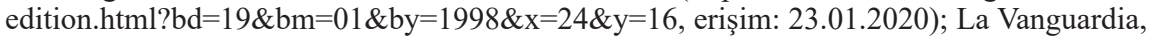
Edición del lunes 09 de marzo de 1998. (http://hemeroteca.lavanguardia.com/edition.html? $b d=09 \& b m=03 \& b y=1998 \& x=26 \& y=10$, erişim: 23.01 .2020 )

49 ECJ, Google Spain SL, Google Inc v. Agencia Espanola de Proteccion de Datos (AEPD), Mario Costeja Gonzalez, 13 May 2014, Judgment of The Court (Grand Chamber), §1415. (https://eur-lex.europa.eu/legal-content/EN/TXT/?uri=CELEX\%3A62012CJ0131, erişim:18.01.2019).

50 ECJ, Google v. Spain, $§ 19$.

Ankara Hac1 Bayram Veli Üniversitesi Hukuk Fakültesi Dergisi C. XXIV, Y. 2020, Sa. 2371 
ruling) $)^{51}$ talebinde bulunmuştur ${ }^{52}$. Görüş talep ettiği hususlardan biri, başvuranın silme talebinin unutulma hakkı (derecho al olvido) ile ilişkisine dairdir.

ABAD, 95/46/EC sayılı Direktifin ${ }^{53}$ ilgili hükümlerine ve $A B$ Temel Haklar Sözleşmesine dayanarak ${ }^{54} 13$ Mayıs 2014'te başvuruya ilişkin görüşünü açıklamıştır. Söz konusu kararda; kişisel verilerin, Temel Haklar Sözleşmesinin 7 ve 8 . maddeleriyle güvence altına alındığ 1 , bu nedenle Direktif' in 6/1-c-e maddesine uygun olarak yeterli, ilgili ve amacı aşmayacak şekilde işlenen verilerin zamanla "yetersiz, ilgisiz, artık ilgisiz ya da aşırı" hale gelmesi durumunda silinmesi gerektiğ ${ }^{55}$; ancak bu veriye ulaşmada üstün bir kamu yararı bulunması halinde özel hayatın korunması kapsamında gördüğü unutulma hakkının kullanılamayacağı belirtilmiştir ${ }^{56}$. Başka bir ifadeyle insanların haber, görüş ve bilgiye ulaşma haklarını da güvence altına alan ifade hürriyeti ile unutulma hakkı arasında her davanın özel koşulları dikkate alınarak bir denge (balancing) kurulmalıdır. ${ }^{57} \mathrm{Bu}$ denge kurulurken bilginin niteliği, veri sahibinin özel hayatı açısından hassasiyeti, insanların ilgili veriye ulaşmalarındaki kamu yararı ve uygulama maliyeti ${ }^{58}$ dikkate alınmalıdır. Elbette kamu yararı ile veri sahibinin kamu hayatında oynadığı rol arasında yakın bir ilişki bulunmaktadır. ${ }^{59}$

51 Avrupa Birliği Antlaşması ve Avrupa Birliğinin İşleyişi Hakkında Antlaşma'nın 267.maddesine göre ulusal mahkemelerce ABAD'a antlaşmaların yorumu ile Birlik, kurum, organ, ofis veya ajanslarının tasarruflarının geçerliliği ve yorumuyla ilgili ön karar başvurusunda bulunabilmektedirler. Avrupa Birliği Antlaşması ve Avrupa Birliğinin İşleyişi Hakkında Antlaşma. (https://www.ab.gov.tr/files/pub/antlasmalar.pdf, erişim:23.03.2020).

52 ECJ, Google v. Spain, §20.

53 Directive 95/46/EC of The European Parliament and of the Council of 24 October 1995 on the protection of individuals with regard to the processing of personal data and on the free movement of such data. (https://eur.-lex.europa.eu/LexUriServ/LexUriServ. do?uri=CELEX:31995L0046:en:HTML, erişim:18.01.2019).

54 ECJ, Google v. Spain, §1.

55 ECJ, Google v. Spain, §92-93-94.

56 ECJ, Google v. Spain, §81, 97.

57 ECJ, Google v. Spain, §74, 76, 81.

58 ECJ, Google v. Spain, §99. ECJ, Google Inc v. Commission nationale de l'informatique et des libertés (CNIL), 24.09.2019, Judgment of The Court (Grand Chamber), §45, (http:// curia.europa.eu/juris/document/document.jsf;jsessionid=21BC6D93073108F79E082D650 6 DF3544 text $=\&$ docid $=218105 \&$ pageIndex $=0 \&$ doclang $=E N \&$ mode $=1$ st $\&$ dir $=\& o c c=$ first \&part=1\&cid=12866, erişim:14.01.2020).

59 ECJ, Google v. Spain, §81, 97, 99. 
Silme hakkı ve özel hayat hakkı ile ilişkilendirerek de olsa unutulma hakkı kavramına açıkça yer veren ${ }^{60}$ ve hangi koşullarda kullanılabileceğini ortaya koyan bu karar, Google'ın bireyin unutulmasına hizmet eden silme taleplerini dikkate almasında, unutulma hakkı teriminin uluslararası hukuk metinlerinde ve AİHM kararlarında yer bulmasında etkili olmuştur.

\section{A. Google'ın URL Kaldırma Taleplerine Yaklaşımı ve Şeffaflık Raporu}

Google bu kararın ardından, kişilerin ${ }^{61}$ erişim engelleme ya da Tekdüzen Kaynak Bulucu (Uniform Resource Locator- URL) kaldırma taleplerini inceleme uygulamasına başlayarak, unutulma hakkının hayata geçirilmesinde önemli bir adım atmıştır ${ }^{62}$. Google tarafından hazırlanan Şeffaflı Raporunda "yetersiz, ilgisiz, artık ilgisiz veya aşırı" olduğu düşünülen bağlantıların talep halinde, ABAD'ın Google v. Spain kararında unutulma hakkının istisnas1 olarak gördüğü üstün kamu yararının dikkate alınarak kaldırılabileceğini ifade edilmiştir ${ }^{63}$. Buna göre Google, talepleri değerlendirmekte ve bunlardan uygun gördüklerini kabul ederek söz konusu URL'yi kaldırmaktadır. Google, içeriğin hassas bilgilere ${ }^{64}$, küçük yaşlarda gerçekleştirilen önemsiz suçlara ${ }^{65}$, infaz edilmiş hükme ya da beraate ilişkin olmasi ${ }^{66}$ ve ilgili verinin varlığının

${ }^{60}$ Söz konusu kararda unutulma hakk1, biri İspanya Ulusal Yüksek Mahkemesinin sorusu olmak üzere toplam iki kez geçmektedir. Bu hak, Ulusal Yüksek Mahkemenin sorusunda, silme ve itiraz hakkıyla ilişkilendirilmiş, Adalet Divanının kararında ise kişisel verilerin korunması ve özel hayat hakkıyla birlikte kullanılmıştır. Bkz. ECJ, Google v. Spain, §20, 91.

${ }^{61} \mathrm{Bu}$ kişilerin kim olduğu Google tarafından belirtilmiştir: "Tüzel kişi, vefat etmiş kişi (vefat edenin adina başvurulabilir), devlet yetkilisi, reşit olmayan kişi, devletle ilgisi olmayan kamuya mal olmuş kişi, özel şahıs”, Google, Transparency Report. (https://support.google. com/transparencyreport/answer/7347822, erişim:11.01.2020).

62 Google- İçerik Kaldırma Talep Formları. (https://support.google.com/legal/ answer $/ 3110420$ ?hl=\&visit $\_$id $=636834292441526880-2173035487 \& \mathrm{rd}=2 \quad$ erişim: 18.01.2020).

63 Google, Şeffaflık Raporu, “URL'nin gizlilik Nedeniyle Google Arama'dan Kaldırılması”. (https://transparencyreport.google.com/eu-privacy/overview, erişim:11.01.2020).

64 "Bir kişinin yalnızca sağlığı, cinsel yönelimi, ırkı, etnik kökeni, dini, siyasi görüşü ve sendika durumuna ilişkin bilgilerle ilgili içeriğe sahip sayfalar." Google, Transparency Report. (https://support.google.com/transparencyreport/answer/7347822\#requester , erişim:16.01.2020).

65 "Küçüklerle veya talepte bulunan kişinin küçük olduğu dönemde gerçekleşmiş önemsiz suçlarla ilgili içerik." Google, Transparency Report, https://support.google.com/transparencyreport/answer/7347822\#requester (16.01.2020).

66 "Suçluların rehabilitasyonuyla ilgili yerel yasaya uygun şekilde, infaz edilmiş hüküm, mahkemede yanlış olduğu kanıtlanan suçlama veya talepte bulunanın temize çıktığı bir cezai kovuşturmayla ilgili içerikler." Google, Transparency Report. (https://support.google.com/ 
açık bir şekilde kamu yararına hizmet etmemesi ${ }^{67}$ durumunda, URL'nin arama sonuçlarından kaldırılması lehine karar vermeye yatkın olduğunu ifade etmiştir ${ }^{68}$. Aynı raporda içeriği arama motorlarından kaldırmama nedenleri de açıkça belirtmiştir:

"Sayfaların arama sonuçlarından kaldırılmaması kararlarında etkili olan bazı genel faktörler şunlardır: alternatif çözümlerin olması, teknik nedenler veya yinelenen URL'ler. Ayrıca, sayfanın içerdiği bilgilerin kamu yararı için önemli olduğunu belirleyebiliriz. İçeriğin kamu yararına olup olmadığının belirlenmesi karmaşık bir süreçtir ve talepte bulunan kişinin mesleki yaşamı, eski bir suç olup olmadığı, siyasi mevkisi, kamu hayatındaki konumu veya içeriğin ilgili kişinin kendisi tarafından yazılmış olup olmadığı, devlet belgelerinden oluşması ya da gazetecilik niteliği taşıması gibi ancak bunlarla sınırlı olmaksızın birçok farklı etkenin dikkate alınması anlamına gelebilir." 69

transparencyreport/answer/7347822\#requester, erişim: 16.01.2020).

67 "Örneğin, kişisel iletişim veya adres bilgileri içeren sayfalara sahip toplayıcı siteler, talepte bulunan kişinin adının sayfada artık görünmediği örnekler ve artık çevrimiçi olmayan (404 hatas1) sayfalar." Google, Transparency Report. (https://support.google.com/transparencyreport/answer/7347822\#requester, erişim:16.01.2020).

68 Google, Transparency Report. (https://support.google.com/transparencyreport/answer/7347822, erişim:27.12.2019).

69 Google, Şeffaflık Raporu, "URL'nin gizlilik Nedeniyle Google Arama'dan Kaldırılması". (https://transparencyreport.google.com/eu-privacy/overview, erişim: 22.03.2020). 
Tablo 1. Kaldırılması Talep Edilen ve Arama Sonuçlarından Kaldırılan URL'ler $^{70}$

( Başlangıç: 28.05.2014, Bitiş:22.03.2020)

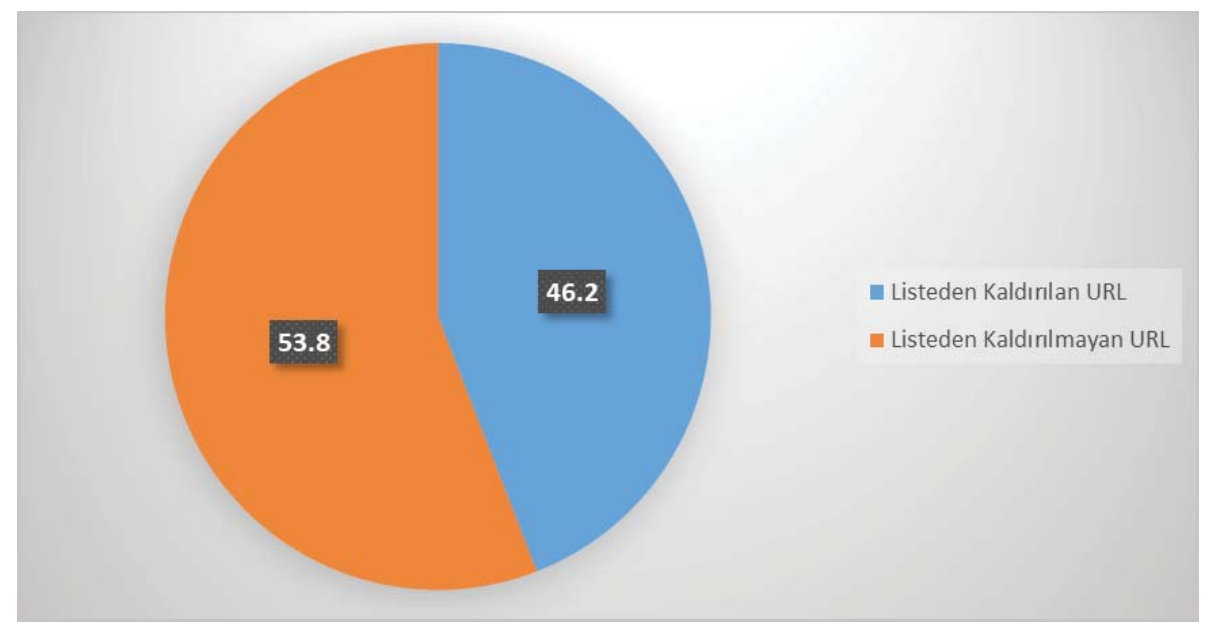

Google son Şeffaflk Raporunda, hangi internet sitelerinin URL kaldırma taleplerinden etkilendiğine dair sayılar vererek, bir grafik oluşturmuştur. $\mathrm{Bu}$ grafik, 28.05.2014 tarihinden beri gelen talepleri kapsamaktadır.

70 Google, Şeffaflık Raporu, “URL'nin gizlilik Nedeniyle Google Arama'dan Kaldırılması”. (https://transparencyreport.google.com/eu-privacy/overview, erişim:22.03.2020). 
Tablo 2. En çok URL'si Kaldırılan Siteler ${ }^{71}$

\begin{tabular}{|c|c|c|}
\hline Alan & $\begin{array}{c}\text { Listeden } \\
\text { kaldırlan URL } \\
\text { sayisi }\end{array}$ & $\begin{array}{c}\text { Talep edilen } \\
\text { toplam URL } \\
\text { sayisi }\end{array}$ \\
\hline www.facebook.com & 23.809 & 57.092 \\
\hline annuaire.118712.fr & 19.933 & 23.155 \\
\hline twitter.com & 17.692 & 38.005 \\
\hline www.youtube.com & 14.125 & 37.851 \\
\hline profileengine.com & 11.567 & 13.427 \\
\hline groups.google.com & 9.416 & 20.337 \\
\hline plus.google.com & 8.937 & 35.570 \\
\hline scontent.cdninstagram.com & 8.305 & 13.974 \\
\hline www.wherevent.com & 6.343 & 7.309 \\
\hline badoo.com & 6.123 & 11.206 \\
\hline
\end{tabular}

B. GDPR ve AİHM Kararlarında Unutulma Hakk1

ABAD'ın Google kararının ardından, Avrupa Parlamentosu kişisel verilerin korunmasını sağlamak amacıyla yeni bir düzenleme arayışına girmiştir. Yapılan çalışmalar sonucunda, 95/46/EC sayılı Direktifi yürürlükten kaldıran ve tüm birlik üyeleri için bağlayıcı olan GDPR, 27 Nisan 2016 tarihinde yayımlanarak 25 Mayıs 2018 tarihinde yürürlüğe girmiştir. Söz konusu Tüzüğün 17. maddesinde ise unutulma hakk, silme hakkı ile ilişkilendirilerek de olsa açıkça düzenlenmiştir ${ }^{72}$. İlgili düzenlemeye göre verinin işlenmesinin artık gerekli olmamasi ${ }^{73}$, kişisel veri sahibi tarafından verilen iznin geri çekilmesi veya ilgili Tüzügün 6 (1)-a ve 9 (2)-a maddelerine

71 Google, Şeffaflık Raporu, “URL'nin gizlilik Nedeniyle Google Arama'dan Kaldırılması”. (https://transparencyreport.google.com/eu-privacy/overview, erişim:22.03.2020).

72 GDPR'ın Türkçe metni için bkz. (https://www.kisiselverilerinkorunmasi.org/mevzuat/ avrupa-birligi-genel-veri-koruma-tuzugu-gdpr-turkce-ceviri/, erişim:14.01.2020).

73 General Data Protection Regulation (GDPR), m.17 (1)-a. 
göre verinin işlenmesi için yasal bir gerekçenin bulunmamas ${ }^{74}$, verinin işlenmesine ilişkin meşru gerekçenin ortadan kalkması ya da Tüzüğün 21 (1) ve 21 (2) maddelerine göre itirazda bulunulmuş olmas $1^{75}$, verinin yasa dışı bir şekilde işlenmiş olması ${ }^{76}$, Birlik ya da Üye Devlet mevzuatına uyum sağlanmas ${ }^{77}$, Tüzügüü 8 (1) maddesi kapsamında bilgi toplumu hizmetlerinin sağlanması ile ilgili toplanmas $1^{78}$ durumunda, veri sahibinin ilgili verilerin silinmesini talep etme hakkı ve ilgili birimlerin mevcut teknolojik olanaklar ile uygulama maliyetini dikkate alarak ${ }^{79}$ herhangi bir gecikmeye mahal vermeksizin verileri silme yükümlülügü bulunmaktadır. Bununla birlikte, söz konusu verilerin silinmesi talebinin; ifade hürriyeti ve bilgi edinme hakkıla çatışmas ${ }^{80}$, verilerin işlenmesinin görev ve mevzuattan kaynaklanması ya da kamu yararı gereği olması ${ }^{81}$, halk sağlığını ilgilendirmesi ${ }^{82}$, yargılamaya ilişkin olmas ${ }^{83}$ halinde bir denge gözetilerek yerine getirilemeyebileceği ifade edilmiştir. Ayrıca kamu yararı, bilimsel, tarihi ya da istatistiksel amaçlarla işlenen verilerin silinmesinin söz konusu amaçların yakalanmasını olanaksız kılması ya da çok zorlaştırması durumunda ${ }^{84}$ da benzer bir uygulamanın yapılacă̆ı hükme bă̆lanmıştır.

Tüzügün kabul edildiği tarih ve unutulma hakkına ilişkin düzenlemenin içeriği dikkate alındığında, düzenlemede ABAD'ın Google v. Spain kararının etkisi açıkça gözlemlenmektedir. Unutulma hakkı terimine açıkça yer verilmesi, hakkın kullanım koşulları ve istisnasına ilişkin konulan ölçütlerin Google v. Spain kararıla paralellik arz etmesi bunun açık göstergesidir.

Google v. Spain kararının ardından unutulma hakkı en azından terim olarak AİHM kararlarında da yer almaya başlamıştır. Avrupa İnsan Hakları Sözleşmesi ve ek protokollerde tanınan ve koruma altına alınan temel haklara

\footnotetext{
74 General Data Protection Regulation (GDPR), m.17 (1)-b.

75 General Data Protection Regulation (GDPR), m.17 (1)-c.

76 General Data Protection Regulation (GDPR), m.17 (1)-d.

77 General Data Protection Regulation (GDPR), m.17 (1)-e.

78 General Data Protection Regulation (GDPR), m.17 (1)-f.

79 General Data Protection Regulation (GDPR), m.17 (2).

80 General Data Protection Regulation (GDPR), m.17 (3)-a.

81 General Data Protection Regulation (GDPR), m.17 (3)-b.

82 General Data Protection Regulation (GDPR), m.17 (3)-c.

83 General Data Protection Regulation (GDPR), m.17 (3)-e.

84 General Data Protection Regulation (GDPR), m.17 (3)-d.
} 
dair ihlal iddialarını inceleyen AİHM, bugüne kadar dört (4) kararında ${ }^{85}$ unutulma hakkı terimine yer vermiştir.

Unutulma hakkı teriminin Mahkeme tarafindan kullanıldığ ilk karar ${ }^{86}$, 2016 tarihli Fürst- Pfeifer v. Avusturya kararıdır. Söz konusu davada bir psikiyatrist olan başvuran, kişisel sağlık bilgilerine bir gazete haberinde yer verilmesi ile ilgili olarak Taraf Devletin itibar hakks (right to reputation) $n \iota$ korumakta yetersiz kaldığını iddia etmiştir. ${ }^{87}$ Mahkeme, itibar hakkının Sözleşmenin 8. maddesiyle bağımsız olarak garanti edilen bir hak olduğunu ifade etmekle birlikte ${ }^{88}$, başvuranın tazminat talebinin ulusal mercilerce reddedilmesini hakkın ihlali olarak görmemiştir. Söz konusu kararı pekçok yönden eleştiren Yargıç Wojtyczek ve Küris ${ }^{89}$ tarafından ortak olarak kaleme alınan muhalef şerhinde unutulma hakkının gereklerinin yerine getirilmediği de ifade edilmiştir ${ }^{90}$ :

"Medyanın zaman içinde sürekli artan olanaklara kavuşmasının bireyin mahremiyetini tehdit etmesi, ulusal ve uluslararası birçok mahkemenin, çok

85 AİHM, M.L. and W.W. v. Germany, B.N.: 60798/10, 65599/10, 28.06.2018; AİHM, Fuchsmann v. Germany, B.N.: 71233/13, 19.10.2017; AİHM, G.I.E.M. S.R.L. and Others v. Italy, B.N.: 1828/06, 34163/07, 19029/11, 28.06.2018; AİHM, Fürst- Pfeifer v. Austria, B.N.: 33677/10, 52340/10, 17.05.2016.

86 Mahkemenin 1984 tarihinde verdiği Malone v. Birleşik Krallık kararının karşı görüşünde, başvuranın telefon görüşmeleri ve kayıtları ile ilgili silme hakkı (right to erasure) terimine yer verildiği görülmektedir. Yargıç Pettiti, haklı ve yasaya uygun bir şekilde kontrol edilen ve tutulan telefon kayıtlarının bile, yargı aşamasının sanığın tahliyesi veya beraati ile sona erdiğinde, elde edilen verilerin silinmesi, bantların iadesi hakkı gibi önlemler gerektirdiğini ifade etmiştir. AİHM, Malone v. The United Kingdom, "Concurring Opinion of Judge Pettiti”, B.N.: 8691/79, 02.08.1984.

87 AİHM, Fürst- Pfeifer v. Austria, B.N.: 33677/10, 52340/10, 17.06.2016, §3.

88 AİHM, Fürst- Pfeifer v. Austria, B.N.: 33677/10, 52340/10, 17.06.2016, §35.

89 Yargıç Wojtczek ve Küris karara konu olan olayda, Mahkemenin yarışan haklara eşit derecede saygı duymadığını, etik gazetecilik ilkelerinden bihaber hareket edildiğini ve Mahkemenin buna adeta göz yumduğunu ve bu şekilde kişinin itibarının zedelendiğini belirtmiștir. AİHM, Fürst- Pfeifer v. Austria B.N.: 33677/10, 52340/10, 17.06.2016, “Joint Dissenting Opinion of Judges Wojtyczek and Küris", §1-6.

902018 tarihinde verilen G.I.E.M. S.R.L. ve Diğerleri v. İtalya kararına yazılan karşı görüşlerden birinde de, benzer şekilde unutulma hakkı terimi kullanılmıştır. Ancak buradaki kullanım, dava konusu olay ile doğrudan ilgili değildir. Davaya emsal teşkil eden 7. Maddede korunan kanunsuz suç ve ceza olmaz ilkesi ile bağlantılı Mahkemenin daha önceden verdiği Varvara v. İtalya (AİHM, Varvara v. Italy, B.N.: 17475/09, 29.10.2013) davasının doğru yorumlanması için unutulma hakkı terimi Yargıç Pinto de Albuquerque tarafindan kullanılmıştır. AİHM, G.I.E.M. S.R.L. and Others v. Italy, B.N.: 1828/06, 34163/07, 19029/11, 28.06.2018, "Partly Concurring, Partly Dissenting Opinion of Judge Pinto de Albuquerque", $\S 21-24$. 
uzun zamandan beri bilinen 'yalnız bırakılma hakkı (right to be left alone)' ya da yakın zamanlarda kullanılmaya başlanan 'unutulma hakkı (right to be forgotten)' gibi kavramlar geliştirmesine neden olmuştur. Mevcut yargılamada ise tam tersi bir tutum takınılmış, bireyin en samimi deneyimlerinin bile ayrıntılarıyla kamuya açıklanmasına izin verilmemesinin medya özgürlüğünü ihlal edeceğine karar verilmiştir."

2017 tarihli bir kararda ise başvuran Fuchsmann tarafindan ilk defa unutulma hakkının ihlal edildiği ileri sürülmüş ve ABAD'ın Google v. Spain kararında kabul edilen unutulma hakkının söz konusu davaya transfer edilmesi talep edilmiştir ${ }^{92}$. Hakkında yolsuzluk iddialarıyla ilgili soruşturma başlatılan başvuran, bu iddiaların Federal Soruşturma Bürosu (US Federal Bureau of Investigation - FBI) raporuna dayanılarak ve başvuranın ismine yer verilerek, The New York Times gazetesinde basılı olarak ve çevrimiçi (online) ortamda yayınlanmasını kişilik hakkının ihlali teşkil ettiğini ve itibarını zedelediğini iddia etmiştir. Mahkeme, 8. madde özelinde iddiaları değerlendirmiş ve söz konusu haber bağlamında gazetenin basın özgürlüğü (m.10) ile kişinin özel hayatına saygı hakkı (m.8) arasında adil bir denge kurmaya çalışmıştır. Mahkeme, yerel yargılama makamların yarışan her iki hak arasında makul bir denge kurduğunu (a reasonable balance between the competing rights) ve kendisine verilen takdir payı (the margin of appreciation) içerisinde hareket ettiğini ifade ederek ${ }^{33}$ ihlal kararı vermemiştir.

Unutulma hakkı teriminin yer aldığı bir diğer karar 2018 tarihli M.L. and W.W. v. Germany başvurusudur. Haklarında adam öldürmekten cezaya hükmedilen ancak yeniden yargılanmasına başlanan başvuranlar hakkında Radyo Programında "katil" ifadesi kullanılmıştır. Bu ifadeye ayrıca, radyo programının internet sitesinde de yer verilmiştir. Başvuranlar özetle, haberin "anonim" olarak verilmeyip isimlerine açıkça yer verilmesinin kişilik haklarını ihlal ettiğini iddia ederek, yerel mahkemeler nezdinde yargılama sürecini başlatmış; ancak tatmin edici bir sonuç alamadıklarından Ai்HM'e başvurmuşlardır. Başvuran, iddiasında kavramsal olarak unutulma hakkının

91 AİHM, Fürst- Pfeifer v. Austria, B.N.: 33677/10, 52340/10, 17.06.2016, “Joint Dissenting Opinion of Judges Wojtyczek and Küris”, §7.

92 AİHM, Fuchsmann v. Germany, B.N.: 71233/12, 19.10.2017, §27. Hükümet ise savunmasında, unutulma hakkına ilişkin görüşlerin ve ABAD'ın ilgili kararının (Google v. Spain) ihmal edilebilir olduğunu, çünkü kararın tamamen farklı koşulları ilgilendirdiğini ve mevcut davayla ilgili bir ilkenin söz konusu olmadığını belirtmiştir. AİHM, Fuchsmann v. Germany, B.N.: 71233/12, 19.10.2017, §28.

93 AİHM, Fuchsmann v. Germany, B.N.: 71233/12, 19.10.2017, §54.

Ankara Hacı Bayram Veli Üniversitesi Hukuk Fakültesi Dergisi C. XXIV, Y. 2020, Sa. 2379 
ihlal edildiğinden bahsetmeyip, internette yer alan bilgilerin belli bir zaman geçtikten sonra unutulmasının mümkün olmadığını, bu durumun da özel hayata saygı hakkının kalıcı ihlali anlamına geldiğini ifade etmiştiri ${ }^{94}$. Alman Hükümeti savunmasında, devletlerin internetin tüm alanlarında hızlı teknik gelişmelerle karşı karşıya kaldıklarını ve ortak bir Avrupa standardı olmadığından ortaya çıkan hukuki problemler karşısında takdir payına sahip olduklarını ifade etmiştir. Bu bağlamda, 95/46/EC sayılı Direktifin, kişisel verilerin silinmesi gereken koşulları belirlediği, ancak unutulma hakkını garanti etmediği ileri sürülmüştür ${ }^{95}$. Mahkeme, değerlendirmeye geçmeden önce ilgili hukuk bölümünde GDPR'de yer alan unutulma hakkına dair düzenlemeye yer vermiştir ${ }^{96}$. Esasa ilişkin incelemesini ise her zamanki gibi unutulma hakkr çerçevesinde değil, özel hayat bağlamında yapmıştır. Mahkeme, özel hayat değerlendirmesinin sonucunda ulusal makamlara tanınan takdir payını gözeterek, ihlal kararı vermemiştir.

Görüldügü üzere, unutulma hakkl, biri başvurucunun iddiasında, diğeri Hükümetin savunmasında, iki tanesi de muhalefet şerhinde olmak üzere bugüne kadar sadece 4 (dört) AİHM kararında yer almıştır. Ancak, yukarıda bahsi geçen kararların hiçbirinde, kararın ana metninde unutulma hakkı terimi kullanılmamış, ihlal iddiaları özel hayatın gizliliği ve ifade hürriyeti arasında bir çatışma olarak ele alınmış, sorun haklar arasında dengeleme yapılarak çözülmüş̧ür ${ }^{97}$.

\section{SONUÇ}

Günümüzde, neredeyse dünyanın her yerinde, mekana, zamana ve hayata dair yeni bir deneyim yaşanmaktadır. Merkezinde bilişim ve iletişim teknolojisinde yaşanan gelişmelerin yer aldığı bu deneyim tarzı bir taraftan bizlere hız, güç, heyecan, kendimizi ve dünyayı değiştirme olanağı sunarken diğer taraftan insan doğası da dahil her şeyi kontrol etmek, değiştirmek ve yok etmekle tehdit etmektedir. Marx ve Engels' in burjuva çă̆ı (modern zamanlar) için kullandığg "katı olan her şey buharlaşıyor, kutsal olan her şey kutsiyetinden arındırılıyor" ifadesi ${ }^{98}$, Komünist Manifesto'nun yazıldığı dönemden çok daha

94 AİHM, M.L. and W.W. v. Germany, B.N.: 60798/10, 65599/10, 28.06.2018, §69.

95 AİHM, M.L. and W.W. v. Germany, B.N.: 60798/10, 65599/10, 28.06.2018, §78.

96 AİHM, M.L. and W.W. v. Germany, B.N.: 60798/10, 65599/10, 28.06.2018, §57-58.

97 "Balancing the competing rights". AİHM, M.L. and W.W. v. Germany, B.N.: 60798/10, 65599/10, 28.06.2018, §89, §95; AİHM, M.L. and W.W. v. Germany, B.N.: 60798/10, 65599/10, 28.06.2018, §32, §54; AİHM, Fuchsmann v. Germany, B.N.: 71233/12, 19.10.2017, §37.

98 MARX/ENGELS, s.56. Marshall Berman, Komünist Manifesto'da yer alan bu ifadeyi mo- 
fazla içinde yaşadığımız bu dönemi tanımlıyor. Yeni deneyimin buharlaştırıp yok ettiği şeylerden biri de hayatı yaşanır kılan, acıların etkisini azaltan, insanın değişmesine ve dönüşmesine zemin hazırlayan unutma olanăğıdır.

Bilişim ve iletişim teknolojisinde yaşanan gelişmelerin ortaya çıkardığı ürün ve uygulamaların istifçi özelliğinin, insan doğasında var olan unutma yetisini tehdit etmesi kişiye, kendisiyle ilgili kişisel verilerin düzeltilmesi, engellenmesi, yok edilmesi, anonim hale getirilmesi ya da silinmesi olanağ tanıyan birtakım yeni hakların gündeme gelmesine neden olmuştur. $\mathrm{Bu}$ haklardan biri de unutulma hakkıdır. Günümüzde çeşitli ulusal ve uluslararası hukuk metinlerinde ve mahkeme kararlarında karşımıza çıkan unutulma hakkının, hukuk kurallarından kaynaklanan, ancak belli koşullarda belli kişilere karşı ileri sürülebilen haklar arasında yer aldığı görülmektedir. Nitekim söz konusu hukuki metinlerin ve mahkeme kararlarının içeriği incelendiğinde unutulma hakkının sadece terim olarak kullanıldığı, unutulmayı değil, unutulmaya hizmet eden çeşitli eylemleri güvence altına aldığı görülür. GDPR'ın 17. maddesinin başlı̆̆ında unutulma hakkının, silme hakkı ile birlikte kullanılması ve madde metninde unutulmadan hiç bahsedilmemesi, unutulma hakkı terimine yer veren uluslararası mahkeme kararlarında da benzer bir yaklaşımın sergilenmesi bunun açık göstergesidir. Oysa insanın acılarından kurtulması, hata olarak gördüklerini geride bırakması, hem iç dünyasında hem de başkalarının gözünde kendini değiştirmesi, özgür iradesini baskı altına alan geçmişinden uzaklaşabilmesi ve kendini gerçekleştirebilmesi için unutulma hakkının hukuk kurallarından ya da sözleşmeden kaynaklanan haklara göre daha fazla güvence sağlayan, kaynağını insan onurunda bulan, bireye uluslararası bir soruşturma ya da çözüm merciine başvurma olanağı veren ve devlete pozitif yükümlülükler yükleyen bir insan hakknna dönüşmesi günümüz dünyası için gereklidir. Bununla birlikte doğalcı temellendirmeden hareketle unutulma hakkının bir insan hakkı olduğunu söylemek teorik zeminde anlam ifade etse de, pratikte söz konusu hakkın bir insan hakkı olarak kabul edilmesini sağlamayacaktır. Bunun için söz konusu hakkın insan hakkı olduğu konusunda uzlaşmaya ihtiyaç vardır. Bu uzlaşının sağlanması ve unutulma hakkının bir insan hakkına dönüşerek yolculuğunu tamamlayabilmesi ise onun bağımsız bir hak olarak ulusal ve uluslararası insan hakları metinlerinde düzenlenmesi, ulusal ve uluslararası mahkeme kararlarında bir insan hakk1 olarak ya da özel hayatın gizliliği kapsamında korunan bir değer olarak ele alınması ile mümkündür.

dern zamanları tanımlamak için kullanmıştır. BERMAN, s.28-29

Ankara Hacı Bayram Veli Üniversitesi Hukuk Fakültesi Dergisi C. XXIV, Y. 2020, Sa. 2381 


\section{KAYNAKÇA}

\section{Kitap ve Makaleler}

AKGÜL, Aydın: "Kişisel Verilerin Korunmasında Yeni Bir Hak 'Unutulma Hakkı' ve AB Adalet Divanı'nın 'Google Kararı'”, Türkiye Barolar Birliği Dergisi, S.116, 2016, s.11-38.

BERMAN, Marshall: Katı Olan Her Şey Buharlaşıyor, Çev. Ümit ALTUĞ; Bülent PEKER, İletişim Yayınları, İstanbul, 16. Baskı, 2013.

BLANCHETTE, Jean-Francois / JOHNSON, Deborah G: "Data Retention and the Panoptic Society: The Social Benefits of Forgetfulness", The Information Society, Vol. 18, No.1, 2002, s.33-45.

BROCK, George: The Right to be Forgotten: Privacy and Media in the Digital Age, Reuters Institute for the Study of Journalism, University of Oxford, London \& New York, 2016.

BYGRAVE, Lee A: "Law and Technology: A Right to be Forgortten?", Communicaton of ACM, January 2015, Vol.59, No.1, s.35-37.

CIAVARELLA, Rachele / TERWANGNE, Cecile De: "Online Social Network and Young People's Privacy Protection: The Role of The Right to be Forgotten" [ (içinde s.157-171) HOF, Simone van der; BERG, Bibi van den; SCHERMER, Bart (Eds), Minding Minors Wandering The Web: Regulation Online Child Safety, Springer Press, BerlinHiedelberg- Verlag2, 014.]

COFONE, Ignacio (Ed): The Right to be Forgotten: A Canadian and Comparative Perspective, Routledge, London, 2020.

CONLEY, Chris: The Right to Delete, Association for the Advancement of Artificial Intelligence-AAAI Spring Symposium Series, 2010.

EBERLE, Edward: "The Right to Informational Self- Determination", Utah Law Review, Vol.4, 2001, s.965- 1016.

ERDOĞAN, Murat: Anayasa Mahkemesine Bireysel Başvuruda Temel Hak ve Özgürlüklerin Yorumu, Lykeion Yayınları, Ankara, 2019.

FIALOVA, Eva: "Data Portability and Informational Self- Determination", Masaryk University Journal of Law and Technology, Vol.8, No.1, Summer 2014, s.47-56. 
FLAHERTY, David H: Protecting Privacy in Surveillance Societies: The Federal Republic of Germany, Sweden, France, Canada and The United States, The University of North Caroline Press, Chapel Hill \& London, 1989.

GÜLENER, Serdar: "Dijital Hafizadan Silinmeyi İstemek: Temel Bir İnsan Hakkı Olarak 'Unutulma Hakkı”, Türkiye Barolar Birliği Dergisi, Y.2012, S.102, s.219-140.

GÜR, İkbal: Kişisel Verilerin Korunması Hususunda AB ve ABD Arasında Çıkan Uyuşmazlıklar ve Çözüm Yolları, Turhan Kitabevi, Ankara, 2010.

HAMMARBERG, Thomas: “Avrupa'da Medya Özgürlüğü ve İnsan Hakları” [ (içinde s.41-56) İfade Özgürlüğ̈̈̈, Avrupa İnsan Hakları Mahkemesi Başkanı Nicolas Bratza'ya İthafen Kaleme Alınmış Makaleler, Council of Europe, 2012.]

HOBOKEN, Joris Van: The Proposed Right to be Forgotten Seen from the Perspective of Our Right to Remember, European Commission Joint Research Centre Institute for the Protection and Security of the Citizen, Publications Office of the European Union, Luxembourg, 2013.

HORNUNG, Gerritt / SCHNABEL, Christoph: "Data Protection in Germany I: The Population Census Decision and the Right to Informational SelfDetermination", Computer Law \& Security Report, Vol.25, Issue.1, 2009, s.84-88.

KALABALIK, Halil: İnsan Hakları Hukuku, Seçkin, Ankara, 2013.

KODDE, Claudia: "Germany's 'Right to be Forgotten'- between the freedom of expression and the right to informational self- determination", International Review of Law, Computers \& Technology, Vol.30, No.1-2, 2016, s.17-31.

KUNDERA, Milan: Gülüşün ve Unutuluşun Kitabı, Çev. Erhan BENER, Can Yayınları, İstanbul, 3. Bask1, 1988.

KÜZECİ, Elif: “İstatistiki Birimler ve Bilgilerin Geleceğini Belirleme Hakkı”, İnsan Hakları Yıllı̆̆ı, Cilt 32, 2014, s.53-75.

MARX, Karl / ENGELS, Friedrich: Komünist Manifesto, Çev. Tanıl BORA, İletişim Yayınları, İstanbul, 1.Baskı, 2018. 
ORWELL, George: 1984, Çev. Celal ÜSTER, Can Yayınları, İstanbul, 47. Bask1, 2014.

RINGELHEIM, Julie: Processing Data on Racial and Ethnic Origin for Antidiscrimination Policies: How to Reconcile the Promotion of Equality With the Right to Privacy?, Center for Human Rights and Global Justice Working Paper No. 13, Jean Monnet Working Paper 08/06, New York University School of Law, New York, 2007.

SALİHPAŞAOĞLU, Yaşar: "Bölüm 4: Jenetik Hukuk Sosyolojisi: Hukuk ve Değişim", [(içinde s.52-70), Hukuk Sosyolojisi, Editör: Yaşar SALİHPAŞAOĞLU, Anadolu Üniversitesi Yayınları, Eskişehir, 2018.]

SCHAAR, Peter: Data Protection and Statics- A Dynamic and TensionFilled Relationship, German Council of Social and Economic Data (RatSWD), Working Paper, No.82, Berlin, March 2009.

SHARMA, Sanjay: Data Privacy and GDPS Handbook, Wiley, New Jersey, 2020.

SCHILLER, Herbert: Zihin Yönlendirenler, Çev. Cevdet CERİT, Pınar Yayınları, İstanbul, 1. Baskı, 1993.

SCHÖNBERGER, Victor Mayer: Delete: The Virtue of Forgetting in the Digital Age, Princeton University Press, Princeton and Oxford, 2009.

SCHWARTZ, Paul: "The Computer in German and American Constitutional Law: Towards an American Right of Informational Self-Determination", American Journal of Comparative Law, Vol. 37, 1989, s.675-701.

SCHWARTZ, Paul M.: "Privacy and Participation: Personal Information and Public Sector Regulation in the United States", Iowa Law Review, Vol.80, 1994-95, s.553-618.

STABEN, Julian: "Consent under Pressure and the Right to Informational Self- Determination”, Internet Policy Review, Vol.1, Issue.4, 2012, s.1-6.

ŞİMŞEK, Oğuz: Anayasa Hukukunda Kişisel Verilerin Korunması, Beta Yayınc1l1k, İstanbul, 2008.

TERWANGNE, Cecile de: "The Right to be Forgotten and Informational Autonomy in the Digital Environment" [ (içinde s.82-101), The 
Ethics of Memory in a Digital Age: Interrogating the Right to be Forgotten, GHEZZI, Alessia; PEREİRA, Angela Guimaraes; VESNICALUJEVIC, Lucia (Eds), Palgrave Macmillan, United Kingdom, 2014.]

UYGUN, Oktay: Devlet Teorisi, On İki Levha, İstanbul, 2014.

YAVUZ, Can: İnternet'teki Arama Sonuçlarından Kişisel Verilerin Kaldırılması Unutulma Hakkı, Seçkin Yayınevi, Ankara, 2016.

\section{Tezler}

AKYÜZ BİLGE, Canan: Unutulma Hakkı ve Türk Hukuku'ndaki Görünümü. Ankara Üniversitesi Sosyal Bilimler Enstitüsü, Yayımlanmamış Yüksek Lisans Tezi, Ankara, 2019.

\section{ÖZ DEMETOĞLU, Gizem: Türk ve Avrupa Birliği Veri Koruma}

Hukuku Bağlamında Blok Zincir Teknolojisinde Unutulma Hakkı, Marmara Üniversitesi Avrupa Araştırmaları Enstitüsü Avrupa Birliği Hukuku Anabilim Dalı, Yayımlanmamış Yüksek Lisans Tezi, İstanbul, 2019.

SÖZÜER, Eren: İnsan Hakları Hukukunda Unutulma Hakkı, İstanbul Üniversitesi Sosyal Bilimler Enstitüsü Kamu Hukuku Anabilim Dalı, Yayımlanmamış Yüksek Lisans Tezi, İstanbul, 2017.

YILDIZ, Tuba: Kişilik Hakları Açısından Unutulma Hakkı, Çankaya Üniversitesi Sosyal Bilimler Enstitüsü Özel Hukuk Anabilim Dalı, Yayımlanmamış Yüksek Lisans Tezi, Ankara, 2019.

YILMAZ, Berrak: Türk Anayasa Mahkemesi ve Avrupa İnsan Hakları Mahkemesi Kararları Işığında Kişisel Verilerin Korunması, Hacettepe Üniversitesi Sosyal Bilimler Enstitüsü, Yayımlanmamış Doktora Tezi, Ankara, 2019.

YILMAZ, Çiğdem: Kişiliğin Korunmasında Unutulma Hakkı. İstanbul Bilgi Üniversitesi Lisansüstü Programlar Enstitüsü, Yayımlanmamış Yüksek Lisans Tezi, İstanbul, 2019.

3. İnternet Kaynakları

65 BVerfGE 1, decision of 15.12.1983. (https://www. bundesverfassungsgericht.de/SharedDocs/Entscheidungen/ 
DE/1983/12/rs19831215_1bvr020983.html, erişim:16.01.2020).

Avrupa Birliği Antlaşması ve Avrupa Birliği’nin İşleyişi Hakkında Antlaşma. (https://www.ab.gov.tr/files/pub/antlasmalar.pdf, erişim:23.03.2020).

Avrupa Birliği Genel Veri Koruma Tüzüğü (GDPR). (https://www. kisiselverilerinkorunmasi.org/mevzuat/avrupa-birligi-genel-verikoruma-tuzugu-gdpr-turkce-ceviri/, erişim:14.01.2020).

BERNAL, Poul A.: 'A Right to Delete?', European Journal of Law and Technology, Vol. 2, No.2, 2011. (http://ejlt.org/article/view/75/144, erişim:23.01.2020).

Council of Europe, European Committee on Legal Co-operation (CDCJ). (https://www.coe.int/en/web/cdcj/home? , erişim:16.01.2020).

Directive 95/46/EC of The European Parliament and of the Council of 24 October 1995 on the protection of individuals with regard to the processing of personal data and on the free movement of such data. (https://eur.lex.europa.eu/LexUriServ/LexUriServ. do?uri=CELEX:31995L0046:en:HTML, erişim:18.01.2020).

ECJ, Google Inc v. Commission nationale de l'informatique et des libertés (CNIL), 24.09.2019, Judgment of The Court (Grand Chamber). (http:// curia.europa.eu/juris/document/document.jsf;jsessionid=21BC6D930 73108F79E082D6506DF3544? text $=\&$ docid $=218105 \&$ pageIndex $=0 \&$ doclang $=E N \&$ mode $=1$ st $\&$ dir $=\& o c c=$ first $\&$ part $=1 \&$ cid $=12866$, erişim: 14.01.2020).

ECJ, Google Spain SL, Google Inc v. Agencia Espanola de Proteccion de Datos (AEPD), Mario Costeja Gonzalez, 13 May 2014, Judgment of The Court (Grand Chamber). (https://eur-lex.europa.eu/legal-content/ EN/TXT/?uri=CELEX\%3A62012CJ0131, erişim:18.01.2019).

EU Kids Online, (http://www.lse.ac.uk/media-and-communications/research/ research-projects/eu-kids-online, erişim:28.03.2019).

European Council, Committee of Experts on Data Protection (CJ-PD), "New Technologies: a challenge to privacy protection ?", 1989. (https:// rm.coe.int/CoERMPublicCommonSearchServices/DisplayDCTMCont ent?documentId=0900001680684607, erişim:15.12.2020).

European Union, Charter of Fundamental Rights of the European 
Union, 26.10.2012. (https://eur-lex.europa.eu/legal-content/EN/ TXT/?uri=CELEX:12012P/TXT , erişim:07.01.2020).

Federal Alman Cumhuriyeti Anayasas1. (http://www.adalet.gov.tr/ duyurular/2011/eylul/anayasalar/ulkeana/pdf/08-ALMANYA\%20209276.pdf , erişim:26.12.2019).

General Data Protection Regulation (GDPR). (https://eur-lex.europa.eu/ legal-content/EN/TXT/HTML/?uri=CELEX:32016R0679\&from=EN\# d1e40-1-1, erişim:16.12.2019).

General Data Protection Regulation Recitals, Recital 65 "Right to Rectification and Erasure". (https://gdpr-info.eu/recitals/no-65/, erişim:15.01.2020).

General Data Protection Regulation Recitals, Recital 66 "Right to be Forgotten". (https://gdpr-info.eu/recitals/no-66/, erişim:15.01.2020).

Google- İçerik Kaldırma Talep Formları. (https://support.google.com/ legal/answer/3110420?hl=\&visit_id=6368342924415268802173035487\&rd=2, erişim:18.01.2019).

Google, Şeffaflık Raporu, "URL'nin gizlilik Nedeniyle Google Arama'dan Kaldırılması". (https://transparencyreport.google.com/eu-privacy/ overview , erişim:06.02.2020).

Google,TransparencyReport. (https://support.google.com/transparencyreport/ answer/7347822, erişim:11.01.2020).

GÜLENER, Serdar / TÜRKÖLMEZ, Onur: "Unutulma Hakkı Perspektifinden Gençler ve Sosyal Medya". (http://www.sbf.sakarya.edu.tr/sites/sbf. sakarya.edu.tr/file/Unutulma_Hakki_Perspektifinden_Gencler_ve Sosyal_Medya.pdf, erişim:16.12.2019).

La Vanguardia, Edición del lunes 09 de marzo de 1998. (http://hemeroteca. lavanguardia.com/edition.html $\mathrm{bd}=09 \& \mathrm{bm}=03 \& \mathrm{by}=1998 \& \mathrm{x}=26$ $\& y=10$, erişim:23.01.2020).

La Vanguardia, Edición del lunes 19 de enero 1998. (http://hemeroteca. lavanguardia.com/edition.html? bd=19\&bm=01\&by=1998\&x=24 $\& y=16$, erişim:23.01.2020).

LASICA, J. D.: “The Net Never Forgets”, Salon, November 26, 1998. (https:// www.salon.com/1998/11/25/feature_253/, erişim:15.12.2019). 
REDING, Viviane. The European Data Protection and Privacy Conference, Brussels, 30 November 2010. (https://ec.europa.eu/commission/ presscorner/detail/en/SPEECH_10_700, erişim:04.12.2019).

REDING, Viviane. The EU Data Protection Reform 2012: Making Europe the Standard Setter For Modern Data Protection Rules in Digital Age, 22 January 2012, Munich, (http://europa.eu/rapid/press-release_ SPEECH-12-26_en.htm, erişim:04.12.2019).

The European Parliament and the Council of The European Union, Directive 96/46/EC of The European Parliament and of the Council of 24 October 1995. (https://eur-lex.europa.eu/legal-content/EN/TXT/PDF/?uri=CE LEX:31995L0046\& from=EN , erişim:07.01.2020). 